\title{
A LATE NEOLITHIC AND EARLY HALAF VILLAGE AT SABI ABYAD, NORTHERN SYRIA
}

\author{
P.M.M.G. AKKERMANS
}

\begin{abstract}
The Early Halaf site at Sabi Abyad, located in the upper Balikh valley of northern Syria, extends over about 4 ha and is one of the larger Halaf settlements in the area. Recent excavations here have revealed a sequence of Early Halaf levels, situated immediately upon Late Neolithic layers. No stratigraphic break seems to be present. New insights into Halaf origins and settlement organization were obtained.

RÉSUMÉ. - Le site halafien ancien de Sabi Abyad, situé dans la haute vallée du Balikh (Syrie du nord), couvre environ 4 hectares et représente l'un des plus grands établissements Halafiens de la région. Des fouilles récentes ont révélé une succession de couches halafiennes anciennes, superposées immédiatement sur des couches néolithiques récentes. Il n'y a pas trace de rupture stratigraphique. Ces fouilles ont livré de nouvelles données tant sur l'origine des Halafiens que sur lorganisation de leurs établissements.
\end{abstract}

\section{INTRODUCTION}

With the kind permission of the Syrian General Direction of Antiquities, excavations were carried out at Tell Sabi Abyad, a Neolithic and Halafian site in the upper Balikh area of northern Syria (1). The location of the site is shown on (fig. 1). The excavations lasted from May 4 to July 41986 and were conducted under the auspices of the University of Amsterdam's Archaeological Mission to Syria (2).

The soundings at Tell Sabi Abyad are part of a regionally oriented research project, aimed at clarifying chronology, settlement patterns and ecology of Halaf society in the Balikh valley of northern Syria. At present, little is known on the nature of Halaf society in Syria, although the Halaf period may be of great importance as an intermediate stage between village economies and early state formation. By means of a regional study, consisting of a combined program of survey and excavation, we hope to gain an insight into the socio-economic structure of Halaf society, into intra- and intersite relations among Halafian settlements, and into the interaction of Halaf society with its natural environment. Specifi-

(1) Our full name for this site is Tell Sabi Abyad I. Rightly, Sabi Abyad is the name for a cluster of sites dating back to the 7th and 6th millennium B.C. and located immediately south of the modern village of Hammam et-Turkman. Henceforth in this article Sabi Abyad stands for Tell Sabi Abyad I.

(2) Accomodation and other facilities were provided by the Dutch team working at the nearby site of Tell Hammam etTurkman. My sincere thanks to dr. Maurits van Loon and dr. Diederik Meijer (directors of the excavations at Tell Hammam et-Turkman). Financial support was granted by the Foundation for Anthropology and Prehistory in the Netherlands and by various Dutch enterprises. cally our project should deal with the following problems :

- date and nature of the introduction of Halaf culture into the Balikh valley. When does Halaf appear in this region and how does it relate to local late Neolithic societies? Is Halaf a foreign or an indigenous development?

- duration of Halaf occupation in the Balikh valley (construction of a local chronology). Are there any indications towards the development of a "local Halaf"?

- the relationship between the individual settlement and the overall settlement system. Which variables underlie the location and role of a settlement?

- nature and extent of the various Halaf settlements. Are there indications of long-term, permanent occupation, or, on the other hand, of short-term and perhaps seasonal occupation? Excavations at Tell Damishliyya have indicated that seasonal occupation should not be excluded as a possibility of Halaf settlement organization (3). Are there any clues towards the size of population per settlement and in the Balikh valley as a whole?

- the relationship between the individual settlement, the overall settlement system and the natural environment. Which subsistence economy and subsistence strategies underlie Halaf society? Which variables of ecological nature underlie the decision of settlement location? Which ecological variables define the socio-economic function of a settlement?

(3) AKKERMANS, in press. 


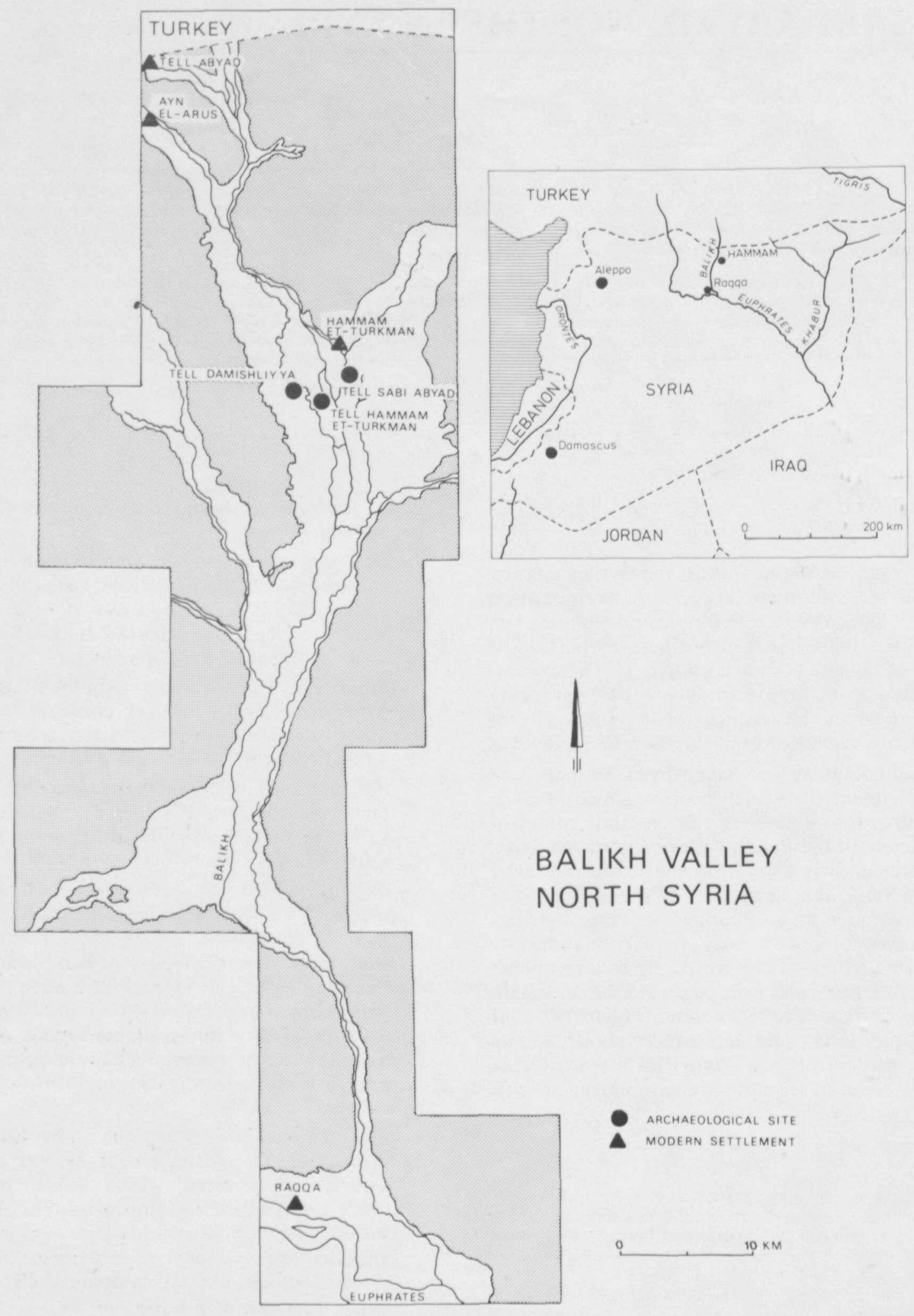

FIG. 1. - Map of the Balikh valley with (inset) its location in Syria. 
Tell Sabi Abyad was selected for excavations for several reasons. The main were that a) on survey evidence and theoretical considerations we thought that Tell Sabi Abyad might represent a permanently occupied settlement, surrounded by smaller « satellites " and perhaps fulfilling a kind of local service function, and b) that surface evidence suggested that Halaf remains could easily be reached at Tell Sabi Abyad.

The first season of excavations at Tell Sabi Abyad has yielded highly valuable information on some of the questions just raised. A detailed analysis is in preparation and here only some preliminary results are presented.

Tell Sabi Abyad is a rather large site, measuring about $240 \times 170 \mathrm{~m}$ (ca. $4.1 \mathrm{ha}$ ). Its height ranges between 5 and $10 \mathrm{~m}$ (fig. 2 and Pl. I : 1). Actually Tell Sabi Abyad is not one, coherent mound but a cluster of several small tells which have merged through time. This clustering of small sites is a very characteristic feature of the 7 th and 6 th millennium sites in the Balikh area. Which variables underlie this grouping of sites is not yet clear. Although in some cases temporal distinctions are obvious, we may speculate that in other cases socio-economic variables played a role. Perhaps kin-related groups each occupied their own territory, clearly distinguished from that of their neighbours.

The oldest occupational remains are found on the north side of Tell Sabi Abyad, whereas the southern part of the tell was inhabited at a later stage. Since virgin soil has not yet been reached, the date of the earliest occupation at Tell Sabi Abyad is not yet known. However, some ceramics found on the surface show close affinities to pottery from the nearby sites of Tell Damishliyya and Tell Assouad, thus suggesting a date in the mid-7th millennium B.C. for these earliest levels at Sabi Abyad.

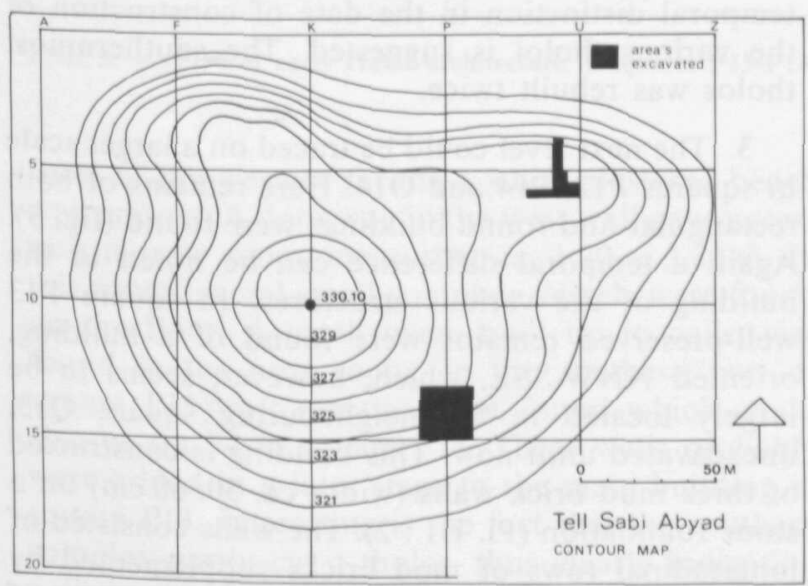

FIG. 2. - Plan of Tell Sabi Abyad. Excavated areas are shown in black.

\section{EXCAVATIONS IN THE NORTHERN AREA}

On the northern slope of Tell Sabi Abyad a test trench $3,5 \mathrm{~m}$ wide was laid out (T4), supplemented by a partly excavated $9 \times 9 \mathrm{~m}$ square (T5). Only in the topmost part did the test trench yield scanty traces of Halafian architectural remains. The larger part of this trench contained a thick accumulation of sloping Halafian debris layers, situated on a similar late Neolithic (4) debris accumulation. Apparently this part of Sabi Abyad was used as a dump for a long time. In a Halafian ash-filled pit, dug from a top floor level into the sloping debris layers, a painted female figurine was found (PI. IV : 2). Large quantities of Halaf and Neolithic pottery were recovered from trench $\mathrm{T} 4$.

The neighbouring square T5 yielded late Neolithic architectural remains immediately underneath the top soil. Here Halaf material was found only in the mixed top soil layer. Probably the Halaf remains have completely eroded on this part of the site. The virtual absence of a substantial accumulation of Halaf remains suggests that the northeastern part of Tell Sabi Abyad was largely a marginal area of the Halaf settlement at the site, inhabited only during a short time or used for specific activities. The late Neolithic levels in square T5 are marked by flimsy architecture. The upper level yielded a large oven, built up in coils. Immediately east of this oven a wall fragment appeared, which probably served as a wind-screen. The underlying levels indicated wall and hearth fragments. Square T5 was marked by soft and dark ashy soil, in which large quantities of coarsely made, plant-tempered ceramics were found, together with a small component of more carefully finished, grit-tempered and often painted ceramics. A few fragments of so-called " husking trays " were also found, showing either rough ridges or (probably finger-impressed) rounded pits.

Interesting is the appearance of some Samarrainfluenced painted pottery in these late Neolithic levels.

Generally, the remains in square T5 gave evidence of an outdoor activity area, outside the actual living quarters.

\section{EXCAVATIONS IN THE SOUTHEASTERN AREA}

Our main efforts were concentrated on the southeastern part of Tell Sabi Abyad, where four squares

(4) The term "Neolithic" is used here to describe the pre-Halaf period. However, it may very well be argued that the Halaf culture itself is a Neolithic society. 
were opened (O13, O14, P13, P14). Here Halaf occupation levels appeared immediately below the surface. A complex sequence of five main Halaf building phases could be established. These Halaf levels were preceded by late Neolithic occupation layers which are closely related to those exposed on the northern part of Tell Sabi Abyad (square T5). No true gap in occupation between the late Neolithic and Halaf periods is indicated.

On the southeastern mound, late Neolithic levels were only reached in square P14. In other squares excavation has been limited to Halafian levels only. As time ran out at the end of the season and no definite clue as to the ultimate duration of Halaf on this part of Tell Sabi Abyad had yet been found, it was decided to limit the actual area of excavation to a two meters wide trench near the east section of square P14. In this way, we succeeded in passing through the accumulation of Halafian levels, and thus reached the underlying Neolithic layers. These late Neolithic levels at Sabi Abyad probably date from the early part of the 6th millennium B.C. A correlation with the Amuq B assemblage is suggested, although true comparisons are only sparsely attested. The characteristic Amuq B Dark-Faced Burnished ware is virtually absent at Tell Sabi Abyad, and, on a regional scale, in the Balikh valley as a whole. The Neolithic levels unearthed thus far at Tell Sabi Abyad are definitely of a date considerably later than those exposed at Tell Damishliyya or Tell Assouad (5).

The late Neolithic levels are characterized by simple rectangular mud brick architecture, although carefully constructed stone foundations also point to more substantial architecture. The introduction of Halaf is marked by the appearance of both rectangular and round buildings. The round buildings of "tholoi" are characteristic trait of the Halafian architectural tradition throughout its area of distribution. The excavations at Tell Sabi Abyad have given clear evidence that here the duality noted in architectural structures is functionally defined. Whereas the rectangular buildings comprised the actual living quarters, the round buildings probably fulfilled a role as storage or kitchen units. The tholoi were all constructed of rather small mud bricks $(25 / 3020 \mathrm{~cm})$ and virtually all had an interior diameter of about 3 meters (Pl. II 1, 2). Usually the wall exterior is white-washed, whereas the interior is marked by a hard burnt plaster, ca. $2 \mathrm{~cm}$ thick.

Most of the floors also indicated such a burnt and well-made plaster, although in several cases floors only consisted of irregular and "wavy" surfaces. However, these irregularly laid floors were also burnt. The burning of the interior of all tholoi is most remarkable, and probably due to the intentional filling of the tholos interior with fuel and subsequent firing of the building. In this manner, a

(5) AKKERMANS, in press; CAUVIN, 1972. very hard floor and wall plaster was created (PI. I : 2). We wish to stress that the interior burning of the tholoi at Sabi Abyad was a planned activity and not an accidental feature. The possibility that these tholoi should be considered as ovens is rejected, in view of the large dimensions and the method of construction of these buildings. Besides, traces of secondary firing were found only once : here a small fire place appeared. Most tholoi contained a small doorway, ca, $60-90 \mathrm{~cm}$ wide (those tholoi without a doorway were either partially uncovered or fragmentarily preserved). In one case a hole serving as a door socket was found (PI. II : 2). Another tholos contained in its centre a stone platform for a wooden post (PI. II : 1); three additional small post holes suggested some kind of room partition. As to the superstructure of these tholoi little is known at present, since virtually all buildings were preserved to a limited height. However, one tholos showed an incurving wall, thus pointing towards a domed roof. This building would only have stood to a man's height.

In view of the limited size and the specific construction of the tholoi at Tell Sabi Abyad, it is quite certain that these buildings were not used for living. The large quantities of burnt cereals found around one of the tholoi may perhaps be considered as supplies originally stored in the building but displaced after its destruction by fire. A storage function is suggested for these tholoi. This is also indicated by the hard, burnt plaster, which may have acted as a highly vermin-resistant coating.

At present, five main Halaf levels, each of which can be subdivided, are distinguishable at Tell Sabi Abyad southeast.

1. The earliest Halafian level was only uncovered on a limited scale in square P14 and yielded solely mud brick debris. Architectural remains are to be expected nearby.

2. The second level indicated the presence of four tholoi, probably surrounding a kind of courtyard. A temporal distinction in the date of construction of the various tholoi is suggested. The southernmost tholos was rebuilt twice.

3. The next level could be traced on a larger scale in squares P13, P14 and O14. Here remains of both rectangular and round buildings were found (fig. 3 ). Again a temporal difference can be noted in the building of the various structures. In square P13 well-preserved remains were found of a building, oriented NNW-SSE, which, however, seems to be largely located in the neighbouring square Q13, unexcavated until now. This building is constructed of thick mud brick walls (width ca. $50 / 60 \mathrm{~cm}$ ) on a stone foundation (PI. III : 2). The walls consisted of longitudinal rows of mud bricks supplemented by bricks of half size. The northern and western faces of this building were white-plastered. Traces of white plaster were also found on the interior wall faces. In 


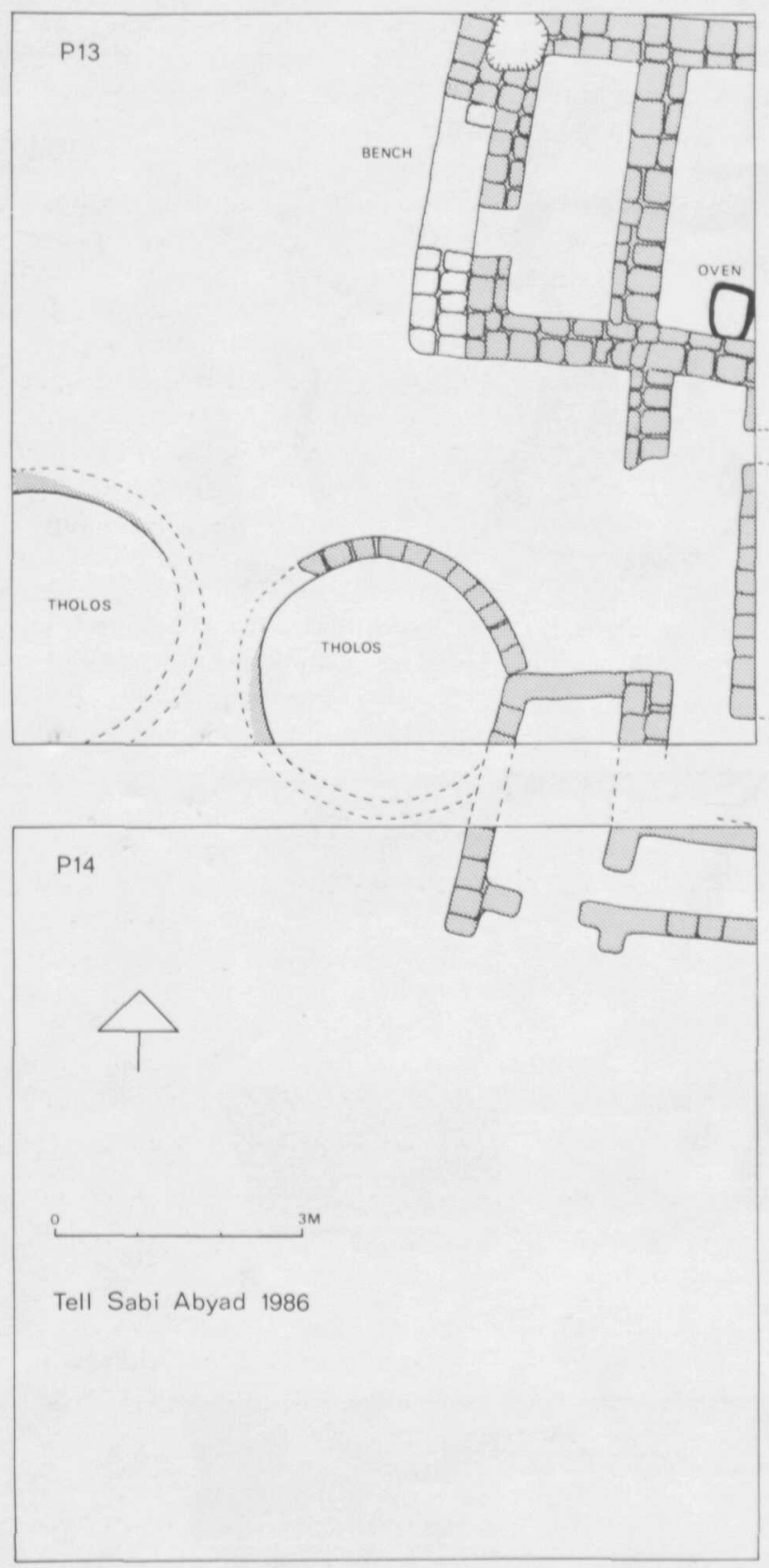

FIG. 3. - Plan of early Halaf architecture in squares P13-P14.

front of the western facade a white-plastered bench was present. A door way in the west wall gave access to a narrow room, measuring ca. $1,20 \times 3,20 \mathrm{~m}$. In this room several small complete vessels were found on the floor. A small oven, built up in coils, was found in the next room. In the southern part of square P13 wall remains were found which could also be traced in square P14. These walls probably were added in a later stage to the main building in square P13. Interesting is the fact that the southern complex partly cut a tholos, thus clearly indicating a distinction in date of construction. This tholos was already out of use when the southern rooms were built, but apparently still stood to a considerable height. To the west, next to this tholos, another one was present. Both tholoi were heavily disturbed by later building activities and could only be reconstructed here on the basis of fragments. The southern complex was built of small mud brick walls, simply founded on earth. The well-laid stone foundations characteristic of the northern complex are not found here. A doorway, marked on both sides by buttresses, gave access to a series of tiny rooms.

In square $\mathrm{O} 14$, too, traces of rectangular architecture appeared which may be related to the present complex in squares P13-P14. However, the larger part of the remains in square $\mathrm{O} 14$ was destroyed by building activities of the late 2 nd millennium B.C.

Generally, Tell Sabi Abyad gives the impression of a rather open scatter of buildings. The site does not seen to have been densely built over. In square P14 the larger part of the area excavated was not built up and the neighbouring squares also indicate large open areas. This open village structure shows close similarities to the outline of modern villages in the Syrian Jezirah; here, too, isolated rectangular houses appear, surrounded by small, round and domed buildings which are used for several purposes, e.g. as storage rooms or as chicken-coops (Pl. III-1).

4. The fourth level of Halaf occupation at Sabi Abyad shows a completely different outline. The larger part of the formerly built-up area now seems to be in use for open-air domestic activities. The level in question is marked by a thick accumulation of ashes and debris. Several ovens and fireplaces appeared, together with some small tholoi. The most remarkable architectural feature now is a small keyhole-shaped kiln, the larger part of which was sunk into earlier layers (PI. IV : 1). Traces of mud brick and of walls curving in toward the top suggest that this kiln had a dome-shaped mud brick superstructure. The kiln consisted of an absidal combustion chamber, about $160 \mathrm{~cm}$ long, $75 \mathrm{~cm}$ wide and sunk into the ground to a depth of $70 \mathrm{~cm}$, and a circular heating chamber, about $120 \mathrm{~cm}$ in diameter and also ca. $70 \mathrm{~cm}$ deep. The kiln interior was mud-plastered. This mud plaster, however, showed only superficial traces of firing, thus indicating that the fire itself did not reach very high temperatures. The combustion chamber was largely filled up with dark ash in which many bones but also sherds were found. The additional heating chamber was directly connected to the combustion chamber without any intermediate grate or the like. The heating chamber was partly filled up with heat-cracked stones. An opening was probably present on the western side. As to the function of this kiln we may only speculate for the moment. The present evidence suggests that the fire in the combustion chamber mainly served to heat the stones in the next chamber, which thus may have been used e.g. for the roasting or drying of meat or cereals. It is very unlikely that this kiln was used for pottery production, in view of its construction, the probably limited temperatures reached in 

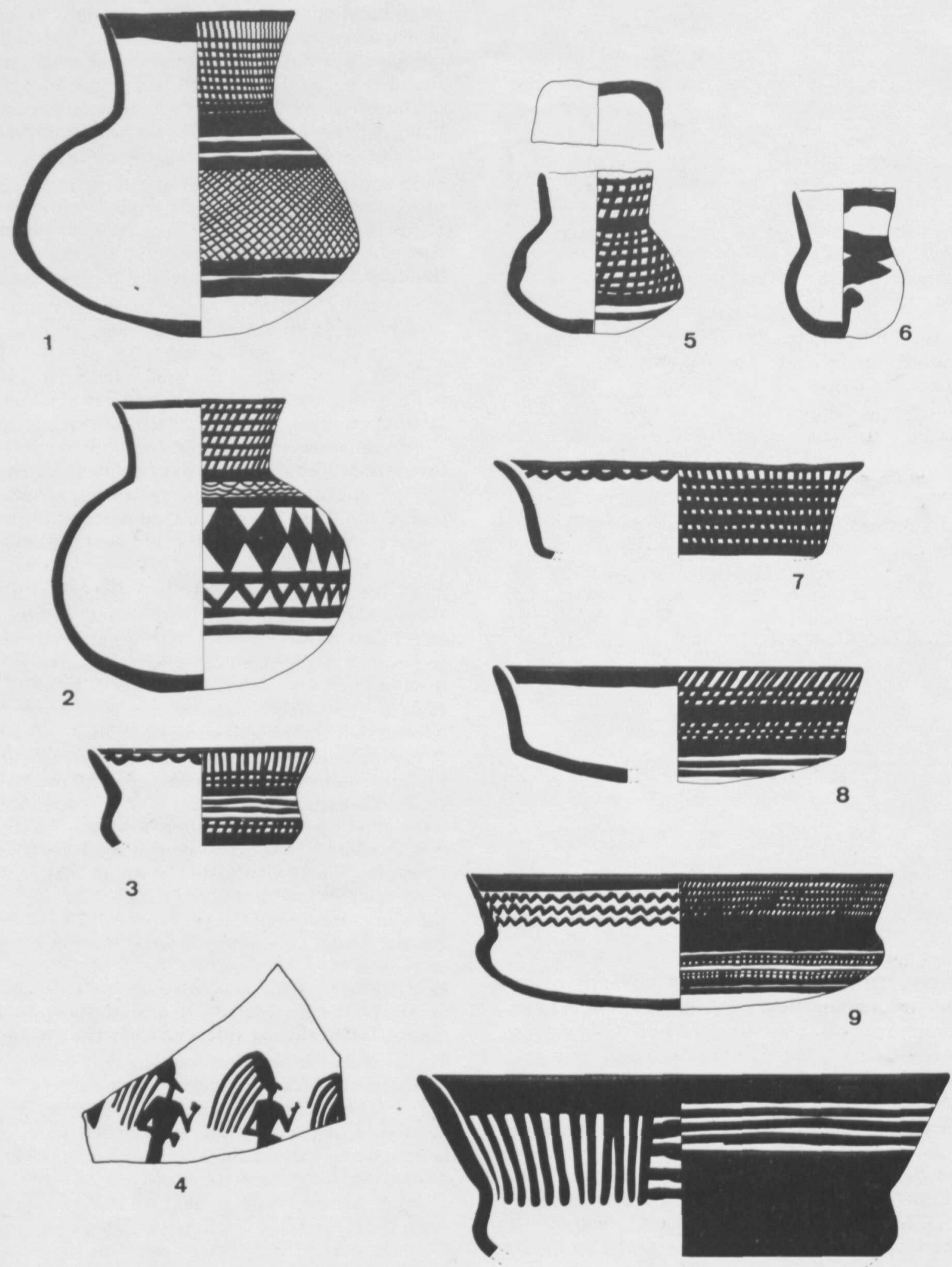

10

FIG. 4. - Early Halaf pottery from Tell Sabi Abyad (nos. 1-3, 5-10 scale 1:3; no. 4 scale $1: 2$ ). 
the kiln and the absence of wasters in its immediate vicinity.

Northeast of the keyhole-shaped kiln a bread oven appeared, which was preserved to a height of ca. $60 \mathrm{~cm}$. Next to this oven a fireplace was present. Several complete vessels were found on the floor surrounding this oven. Above this floor a cylindrical-shaped and longitudinally pierced seal or amulet was also found, made of slightly baked clay (PI. IV : 3 ). It is, however, uncertain whether this small find is a true Halaf artifact or an intrusive element in the present level (perhaps worked down by animal activity). Our seal shows some resemblance to late 2nd millennium cylinder seals from western Syria and the Levant.

5. The topmost Halafian level on the southeastern shoulder of Tell Sabi Abyad is marked by a large rectangular complex, oriented almost north-south. Several small rooms appeared, measuring from $3.00 \times 1.25 \mathrm{~m}$ to $2.60 \times 1.50 \mathrm{~m}$. The walls were partly dug in. A simple mud floor was found in all areas. White plaster fragments in some rooms suggest that originally a coating was present on the various walls. No tholoi are ascribed to this phase; their apparent absence may, however, be due to erosion. The southern part of the building, in particular, situated on the gentle tell slope, was disturbed by erosion. The whole complex, which appeared immediately below the tell surface, was preserved to a height of no more than one to three bricks.

\section{HALAF POTTERY}

Thousands of sherds and several complete vessels were recovered from the Halafian layers at Tell Sabi Abyad. The pottery constitutes a coherent assemblage and may in traditional terms (6) be ascribed to the early Halaf period. A date in the mid-6th millennium B.C. is suggested (7). The vast majority of the pottery was busily painted. Lustrous painting is common although matt painting also occurs in large numbers. Most of the ceramics carry simple geometric designs, but naturalistic motifs also appear. A few sherds show human images (fig. $4: 4$ ). Virtually all painted ceramics are lime-tempered and well-fired. Black cores are absent, but slightly grey cores do appear.

The painted pottery shows only little variety in vessel shape. Large flat-based bowls with straight walls are numerous. Cream bowls also constitute a common feature throughout the Halaf sequence at

(6) The main periodization of the Halaf culture is derived from the excavations at Tell Arpachiyah, cf. MALLOWAN and ROSE, 1935.

(7) Several C14 samples were collected at Sabi Abyad but the laboratory dates are not available yet.
Tell Sabi Abyad. Two varieties of cream bowls are noted : a large, tall-collared shape and a smaller, thin-walled and low-collared type. Jars and pots mainly indicate a globular body with flattened base and flaring collar. They virtually always display a sharp junction between neck and shoulder.

Highly remarkable is the appearance of low but consistent numbers of ceramics painted in Samarra style. Most Samarra-influenced pottery is jar-shaped, but restricted and carinated bowls are also found (fig. $6: 22-27$ ). All of this pottery was probably locally made (8). Some vessels, which in shape and exterior design clearly display Halaf traits, indicate Samarra influences by their interior decoration, e.g. the so-called "dancing ladies" (a common interior design at Sabi Abyad). Apparently an interaction existed between the early Halaf and Samarra societies. The Halaf potter incorporated Samarra designs and shapes into the traditional Halaf repertoire.

Samarra and Samarra-influenced pottery has been found in a Halaf context at several sites in Syria and Iraq, e.g. Tell Aqab, Chagar Bazar, Tell Halaf, Nineveh, Arpachiyah and Yarim Tepe II. At Tell Aqab a few Samarra-like sherds were found in middle Halaf levels, but fabric and technique of manufacture indicated that these sherds were Halaf products (9). At Tell Aqab no pottery with Samarran affinities was found in early Halaf levels (10) and Davidson (11) favours a late date, viz., middle and late Halaf periods, for Samarran influences on Halaf pottery, but admits that at Chagar Bazar 15-13 already Samarra or Samarra-related ceramics appeared in an early Halaf context. At Arpachiyah Sa. marra-like pottery also seems to be present in early Halaf layers (12). At Nineveh, Samarra-style painted pottery precedes the appearance of Halaf ceramics at the site, although for some time a coexistence between both traditions is perceptible. The Nineveh deep souding yielded Samarra pottery in level 2 (b), whereas in level 2(c) Samarra pottery appeared together with Halaf ware (13). A similar development seems to have taken place at Sabi Abyad : here Samarra-like pottery is already present in late Neolithic levels, whereas at a later stage Samarra ware is found side by side with early Halaf ceramics.

(8) A petrological analysis is planned to test this assumption. (9) DAVIDSON, 1977: 110

(10) The limited exposure of early Halaf levels at Tell Aqab makes it hard to gain an insight into early Halaf pottery variability at the site. Early Halaf levels were reached only in a small sounding measuring $4 \times 1.5 \mathrm{~m}$ at the southern end of trench S3. A sample of only 482 sherds is ascribed to the early Halaf period at Tell Aqab (DAVIDSON, $1977: 109$ ).

(11) DAVIDSON, $1977: 251 \mathrm{ff}$. 169 .

(12) i.e. pre-TT 10 levels, cf. MALLOWAN and ROSE, 1935

(13) MALLOWAN, $1933: 132$. Level 2(c) at Nineveh seems to represent a mixed deposit. Some obviously early Halaf sherds were found together with trichrome painted pottery which no doubt belongs to a late Halaf phase. 

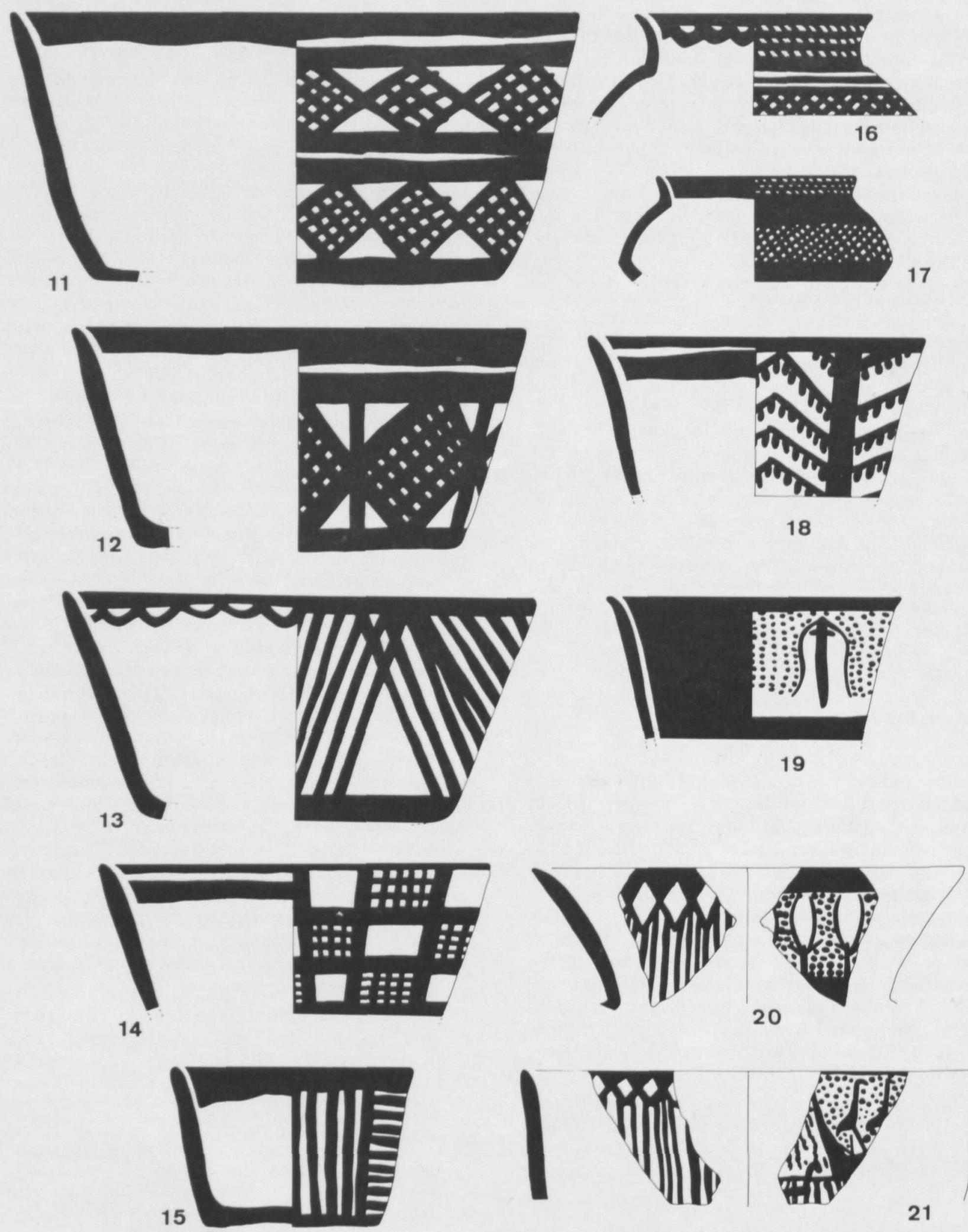

FIG. 5. - Early Halaf pottery from Tell Sabi Abyad (scale 1:3). 
Beside the painted ceramics, a smaller component of brown-orange, sand or plant-tempered and undecorated "coarse ware" appeared. Most of these vessels are either simply scraped or burnished, Vessel shapes include thick-walled bowls, low-collared pots and hole-mouth vessels, which sometimes carry a lug handle (fig. $6: 28-32$ ).

Along with the Halaf painted and unpainted wares, a group of grey-black burnished vessels appeared. These sand or lime-tempered ceramics have a brittle, granular texture. This pottery seems to have been produced in a reducing atmosphere, which caused a blackening of the vessel wall by carbon deposition. Generally, the wall section of these vessels displays a grey or black colour throughout, without a distinct core. Only few vessel shapes are indicated. Most common are wide and flaring bowls which show a carination. Beside these carinated vessels, simple low-necked jars and hole-mouth pots appeared. One such hole-mouth pot indicated a spout. Clear parallels for this spouted vessel are found in the "Altmonochrome" ware of Tell Halaf(14). The grey-black burnished pottery at Tell Sabi Abyad seems to be limited to the early Halaf period. No such pottery was found in a late Neolithic context. Besides, the shapes have clear counterparts in the Halaf painted ware, thus indicating a close interrelationship.

Burnishing constitutes a characteristic feature of early Halaf pottery assemblages. At Tell Aqab in the upper Khabur region about $37 \%$ of the early Halaf pottery sample consisted of burnished ware (15). Burnished pottery is also found in an early context e.g. at Tell Halaf, Chagar Bazar and Arpachiyah. Some pattern-burnished bowl fragments found in Halaf strata at Sabi Abyad compare to a rare sherd recovered from an early level at Aqab (16). At the latter site, pattern-burnishing is limited to the early Halaf period. Parallels for these pattern-burnished bowls are also found in the "First Mixed Range" of the Amuq, tentatively dated late phase B or early phase $C$ (17). In view of close similarities to ceramics from Sabi Abyad, an early phase C date for the Amuq ceramics seems to be the most likely.

\section{LITHIC INDUSTRY}

Lithic implements appeared in low numbers in the late Neolithic and early Halaf levels at Tell Sabi Abyad. Only about 500 pieces of flint and obsidian were found. The vast majority (ca. $83 \%$ ) of the lithic artifacts were made of flint, which is present within a short distance from Sabi Abyad. Flint outcrops are

(14) VON OPPENHEIM, 1943 : pl. III.

(15) DAVIDSON and WATKINS, 1981:7.

(16) Ibid : 7.

(17) BRAIDWOOD and BRAIDWOOD, 1960: 101 and fig. 80,81 . found on the pleistocene terraces bordering the Balikh floodplain. Flint was brought to Sabi Abyad in the form of nodules and processed locally, as suggested by numerous waste and core fragments. Generally, the lithic industry of Tell Sabi Abyad makes a poor impression. Only few tools are found, e.g. blades, scrapers and borers. A few sickle blades, displaying a gloss on one edge, are present. Arrowheads are virtually absent. Only in the upper Neolithic stratum in trench S5 a coarsely finished point, indicating a crudely retouched tang, was found. This point shows some resemblance to the Levantine Byblos points. True Byblos-type points, however, seem to be limited to the 7 th millennium B.C. In the Balikh valley they were found during excavations at Tell Assouad and Tell Damishliyya (18).

In the Halaf levels at Sabi Abyad no points were found. The faunal remains, however, indicate that hunting still played a role. Within the limited sample of faunal remains investigated in the field about $5 \%$ of the number of bones recovered (or ca. $15 \%$ in weight) consisted of game, e.g. roe, fallow-deer, gazelle and aurochs. Thus hunting implements are to be expected. Perhaps hunting was a specialized activity carried out only by a few members of the community. The distribution of points may hence be limited to specific areas of the site. Another possibility is that other kinds of hunting tools were used, e.g. sling missiles (which, however, were not found at Tell Sabi Abyad), or that points were made of more perishable materials, e.g. wood.

Obsidian was present both in late Neolithic and Halaf strata at Tell Sabi Abyad. The presence of some obsidian waste and microblade cores suggests that obsidian, too, was obtained in the form of small blocks and subsequently chipped locally. Obsidian implements consist mainly of small, unretouched bladelets, although a few larger blades also were found.

In the Halaf period, a variability existed in obsidian distribution at Tell Sabi Abyad, perhaps defined by functional variables or waste disposal patterns. In squares $\mathrm{P} 13$ and P14, representing the actual Halaf occupation areas at Tell Sabi Abyad, about $19 \%$ of the lithic material consists of obsidian. In the Halaf debris area T4, on the northeastern part of Sabi Abyad, this number is reduced to about $14 \%$ of the lithic artifacts. Interestingly enough, the percentage of obsidian in this Halaf debris area T4 compares closely to the amount of obsidian pieces recovered from the late Neolithic strata in square T5; here, too, about $14 \%$ of the lithic material consists of obsidian. These late Neolithic levels on the northeastern part of Sabi Abyad are considered to represent an outdoor activity area, the specific nature of which seems to be confirmed by comparisons to lithic artifact distribution in the Halaf period.

(18) CAUVIN, 1972; AKKERMANS, in press. 

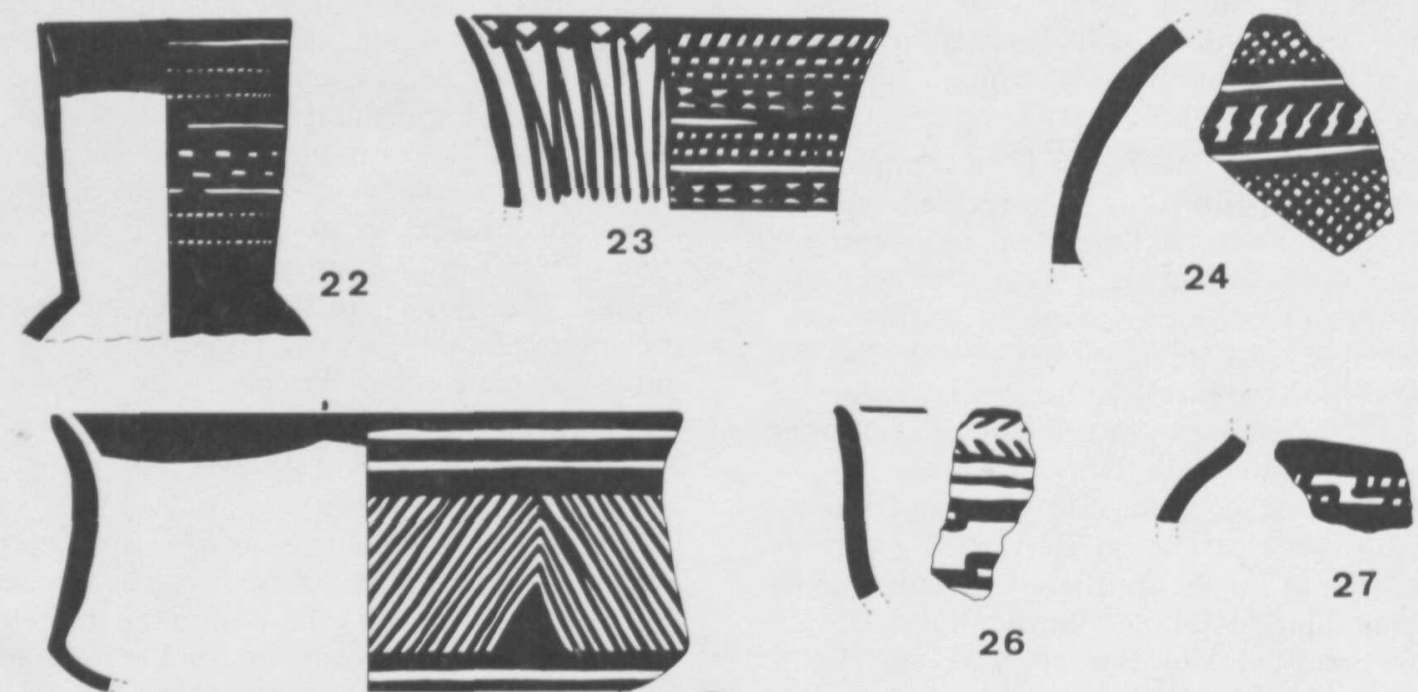

25
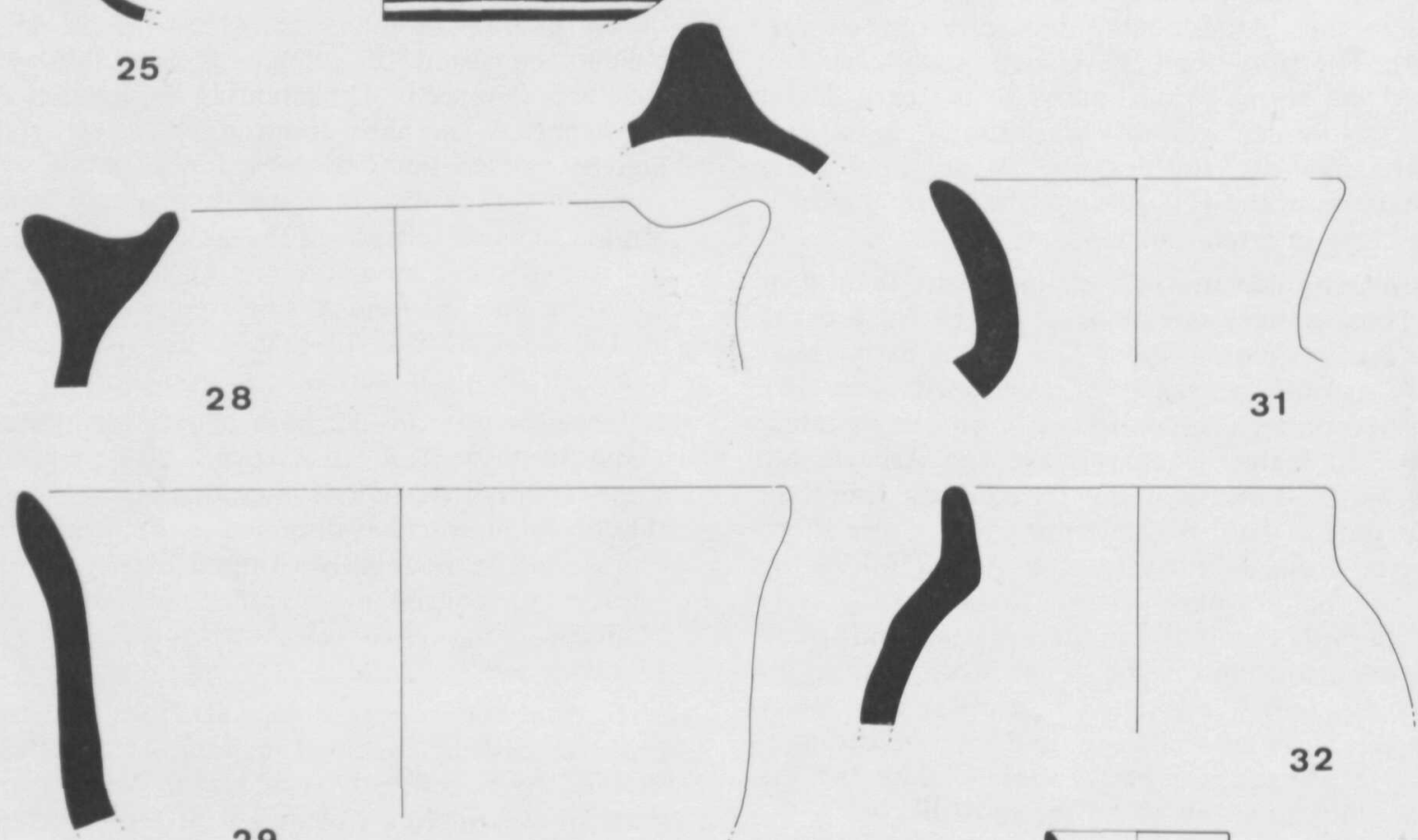

32

29

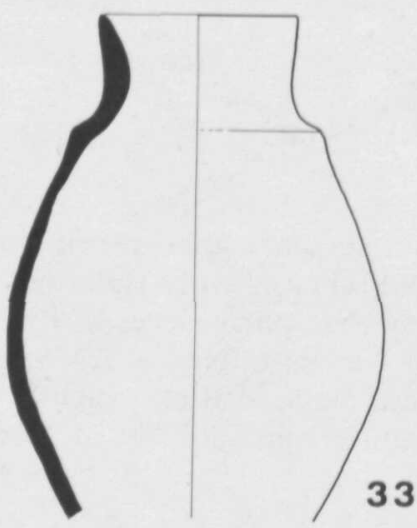

FIG. 6. - Samarra-related pottery (nos. 22-27) and Halaf coarse ware (nos. 28-32) from Tell Sabi Abyad (scale $1: 3$ ). No. 33 represents a Late Neolithic jar found in square P14 (scale 1:6). 


\section{OTHER FINDS}

Relatively few small finds were made at Sabi Abyad.

Stone bowls are rare at Tell Sabi Abyad. Only a few fragments were found, both in late Neolithic and early Halaf levels. Probably pottery had taken over the role of stone vessels. Stone ware seems to constitute a mainly 7 th millennium feature in the Balikh valley. At the Neolithic site of Damishliyya numerous fragments of stone vessels were found, but pottery appeared here only in low quantities.

Some bone awls and spatulas were found in the various Halaf levels at Sabi Abyad. Awls were made of metapodials, whereas spatulas were made on ribs of cattle and sheep or goats. Various bone objects display a polish due to use. A small piece of worked bone shows cut marks of varying length at small intervals. The function of this bone object is unknown (rattle? tally-stick?).

Grinding slabs and pestles, made of basalt, were found both in late Neolithic and early Halaf levels at Sabi Abyad. Traces of use are indicated by smoothed and polished surfaces. One conical-shaped pestle, found in the topmost but one Halaf level on the southeastern mound, showed possible traces of ochre. Basalt seems to have been brought to Sabi Abyad from considerable distance. The nearest sources of basalt are found in the Turkish Karaca Dag area, east of Urfa, or, to the south, in the volcanic area east of Raqqa on the Euphrates. In both cases the distance from the source to Sabi Abyad is the same, viz., about $100 \mathrm{~km}$.

Other finds include conical-shaped spindlewhorls, made of clay, and small, perforated disks, made of sherds. Such perforated and chipped sherd disks may also have been used as spindle-whorls. These perforated objects have been found on many Halaf sites in Syria and Iraq. In the Amuq, they first appeared in a phase B context. At Tell Sabi Abyad conical-shaped clay spindle-whorls and perforated sherd disks were found both in late Neolithic and early Halaf levels.

In a Halaf ashpit in the debris area $\mathrm{T} 4$, on the northern slope of Tell Sabi Abyad, a painted female figurine was found (Pl. IV : 2). The lower part of the body is cube-shaped whereas the upper part is more flattened. Limbs are only superficially indicated and the main emphasis is on breasts and genitals. The head of this figurine is missing. A hole in the neck suggests that the head had been fitted on the body by means of a dowel. Apparently the head was removable or revolving.

An extraordinary small find was made in the topmost but one Halaf level in square P13. Here a slightly baked clay cylinder seal or amulet was found above the floor, south of a bread oven (PI. IV : 3 ). On this floor some complete Halaf vessels were also found, apparently in situ. The cylindrical-shaped and longitudinally pierced seal or amulet shows a highly stylised design, indicating a scorpion, a person with a bow in his arm, an upended quadruped, a tree or other plant, and a possibly horned person with perhaps a sickle in his hand. Although this seal was found in an apparently undisturbed Halaf level, we may have our doubts on an actual Halaf date for this object. The awkwardly executed design somewhat resembles western Syrian and Levantine seals from the end of the 2 nd millennium B.C. (19). Perhaps this seal represents a provincial Syrian Late Bronze II style of seal design (ca. 1400-1100 B.C.). Since occupation levels from this period are present at our site, this assignment is not unlikely. One would have to assume the seal to have been carried down about on meter from the surface through animal burrowing or similar action.

\section{BURIALS}

Two child burials were found at Sabi Abyad, the date of which, however, is uncertain. Both graves were badly preserved and appeared immediately below the top soil on the northeastern mound. One burial was dug into the upper Neolithic level in square T5, whereas the other had been dug into the Halaf debris area T4, on the slope of the north mound. Both burials consisted of simple, unlined pit inhumations. The bodies were laid in contracted position on the left side, facing south. Orientation of the bodies (atlas to sacrum) was east-west and northwest-southeast. No burial gifts were found. These burials may date to the end of the 2nd millennium B.C. or even later (20).

Halaf burials have not been uncovered at Tell Sabi Abyad until now. We expect that a Halaf cemetery, if it existed, will not be found at Tell Sabi Abyad itself, but at a nearby tell. In our case, the most likely places for a Halaf cemetery seem to be the two Pre-Pottery Neolithic sites situated immediately north of Tell Sabi Abyad, at a distance of only several hundreds of meters. Such an expectation is based on analogy with the findings at Yarim Tepe II and surroundings. Here the Halaf settlement is located at Yarim Tepe II, whereas the cemetery is found at the nearby site of Yarim Tepe I (21).

\section{FLORAL AND FAUNAL REMAINS}

From an ecological point of view the excavations at Sabi Abyad yielded some interesting results. The

(19) Cf. HOMÈS-FREDERICQ et al., 1982; COLLON, 1982; TEISSIER, 1984

(20) Cf. BOEHMER and DÄMMER, 1985.

(21) MERPERT and MUNCHAEV, 1973: 108 
floral and faunal remains are currently being investigated at the Biologisch-Archeologisch Instituut in Groningen and at the Instituut voor Prae en Protohistorie in Amsterdam. The following is based on a first preliminary investigation in the field, carried out by $\mathrm{H}$. Buitenhuis and G. de Roller (both of the BAI, Groningen).

By means of flotation 15 soil samples, taken from floor levels, debris layers and refuse pits, were processed for palaeobotanical research. Although some samples were taken close to the tell surface, the preservation of the carbonized vegetable remains is good. Two samples were collected in late Neolithic levels in square T5. These samples mainly include barley grains and ear remains. Wild grasses (Graminae, Galium, Rumex, Bromus and Scirpus) are also present. Samples taken from Halaf debris layers mainly seem to contain fragments of cereal grains and ear remains, thus confirming the specific nature of these rubbish areas. Wheat seems to increase in importance in the Halaf period. The presence of a thick layer of burnt wheat, virtually free of field weeds, around a tholos may represent a burnt stock pile. In several pits large quantities of wheat were also noted.

Large quantities of bones were collected from the various levels at Sabi Abyad. Our excavations yielded unique faunal material which will contribute to our insight into the process of domestication in the Near East. At present, faunal remains belonging to the 6 th millennium B.C. and found in a stratified context are known only from a limited number of sites. In a wider context, one will be able to relate the faunal remains from Sabi Abyad to those of e.g. Bouqras and Shams ed-Din and, in the Balikh valley itself, to the assemblage found at Tell Hammam et-Turkman, Tell Damishliyya and Tell Assouad.

In the field only a limited sample of the total bulk of zoological remains was investigated. A preliminary account of 17 samples, all taken from Halaf levels, is given in table 1. As expected, sheep and goat comprise the vast majority of the faunal remains recovered from Sabi Abyad (about $70 \%$ ). Cattle bones include about $7.7 \%$ of the number of bones found (or 16,8 \% in weight). Large numbers of pig bones turned up $(n=20.8 \%$; weight $=21.9 \%)$. This points to a natural environment different from that found nowadays in the Balikh valley. The presence of fallow deer, gazelle, roe and aurochs also indicates a different environment. On the other hand, the remains of equines (onager?) suggest relations with the steppe. Generally, the faunal remains from Tell Sabi Abyad suggest a wide exploitation of the natural environment. Hunting played an important part. Whithin the limited sample investigated, game included about $5 \%$ of the actual number of bones recovered, or about $15 \%$ in weight. Small game is indicated by bird and fish remains. Fresh-water mussels, too, were brought to the site.
TABLE 1

Bone finds from the early Halaf levels at Tell Sabi Abyad. This list is based on a count of only 17 samples randomly selected out of the total bulk of zoological remains recovered.

\begin{tabular}{|c|c|c|c|c|}
\hline \multirow[t]{2}{*}{ SPECIES } & \multicolumn{2}{|c|}{ NUKBER } & \multicolumn{2}{|c|}{ WEIGHT } \\
\hline & $\mathbb{N}$ & $\%$ & gram & $\%$ \\
\hline $\begin{array}{l}\text { Canis familiaris } \\
\text { Bos taurus } \\
\text { Sus domesticus } \\
\text { small Ruminants } \\
\text { Ovis/Capra } \\
\text { Ovis aries } \\
\text { Capra hircus } \\
\text { Equus spec. } \\
\text { Dama mesopotamia } \\
\text { Capreolus capreolus } \\
\text { Gazella spec. } \\
\text { Gazella/Capreoius } \\
\text { Ares } \\
\text { Unio } \\
\text { Rodents }\end{array}$ & $\begin{array}{l}1 \\
17 \\
37 \\
100 \\
22 \\
21 \\
4 \\
3 \\
1 \\
1 \\
2 \\
5 \\
1 \\
3 \\
2\end{array}$ & $\begin{array}{l}0.4 \\
7.7 \\
16.8 \\
45.4 \\
10 \\
9.5 \\
1.8 \\
1.3 \\
0.4 \\
0.4 \\
0.9 \\
2.2 \\
0.4 \\
1.3 \\
0.9\end{array}$ & $\begin{array}{l}7 \\
480 \\
505 \\
588 \\
126 \\
215 \\
38 \\
261 \\
4 \\
7 \\
23 \\
43 \\
3 \\
-\end{array}$ & $\begin{array}{l}0.3 \\
20.8 \\
21.9 \\
25.5 \\
5.4 \\
9.3 \\
1.6 \\
11.3 \\
0.1 \\
0.3 \\
1.0 \\
1.8 \\
0.1 \\
- \\
-\end{array}$ \\
\hline Total & 220 & 100 & 2300 & 100 \\
\hline
\end{tabular}

\section{DISCUSSION}

The Balikh valley is very suitable for prehistoric research. During our 1983 survey in this region, we found at least 21 sites dating back to the 7 th and early 6th millennium B.C., and about 27 Halaf sites. In 1984 we carried out excavations at Tell Damishliyya, a mainly 7 th millennium settlement (22). Here Pre-Pottery Neolithic and Pottery Neolithic levels were unearthed, which could be compared to those found at Tell Assouad, a site situated about $12 \mathrm{~km}$ north of Tell Damishliyya and excavated in the early 1970's by the French (23). At Tell Damishliyya and at Tell Assouad traces of small-scale Halaf occupation were also found.

The pottery recovered from Tell Damishliyya, Tell Assouad and related sites in the Balikh region, can be dated in the second half of the 7th millennium B.C. (ca. $6600 / 6500-6000$ B.C.). Originally, the pottery from Tell Assouad was compared by its excavator to that of the Amuq phases A-B (24) but recent research has clearly indicated that these ceramics (and those of the related Balikh sites) precede the Amuq A-B assemblages (25). Survey evidence from the Balikh valley (26) suggests a flourishing local Neolithic culture in this region during the later half of the 7th millennium B.C., which seems to come to an end around $6000 / 5900$ B.C. At this time, a trend towards site abandonment is perceptible in vast areas of the

(22) AKKERMANS, in press.

(23) CAUVIN, 1972.

(24) Ibid.

(25) Cf. COPELAND, $1979: 266$; LE MIĖRE, $1979: 38$.

(26) COPELAND, 1979; AKKERMANS, in preparation. 

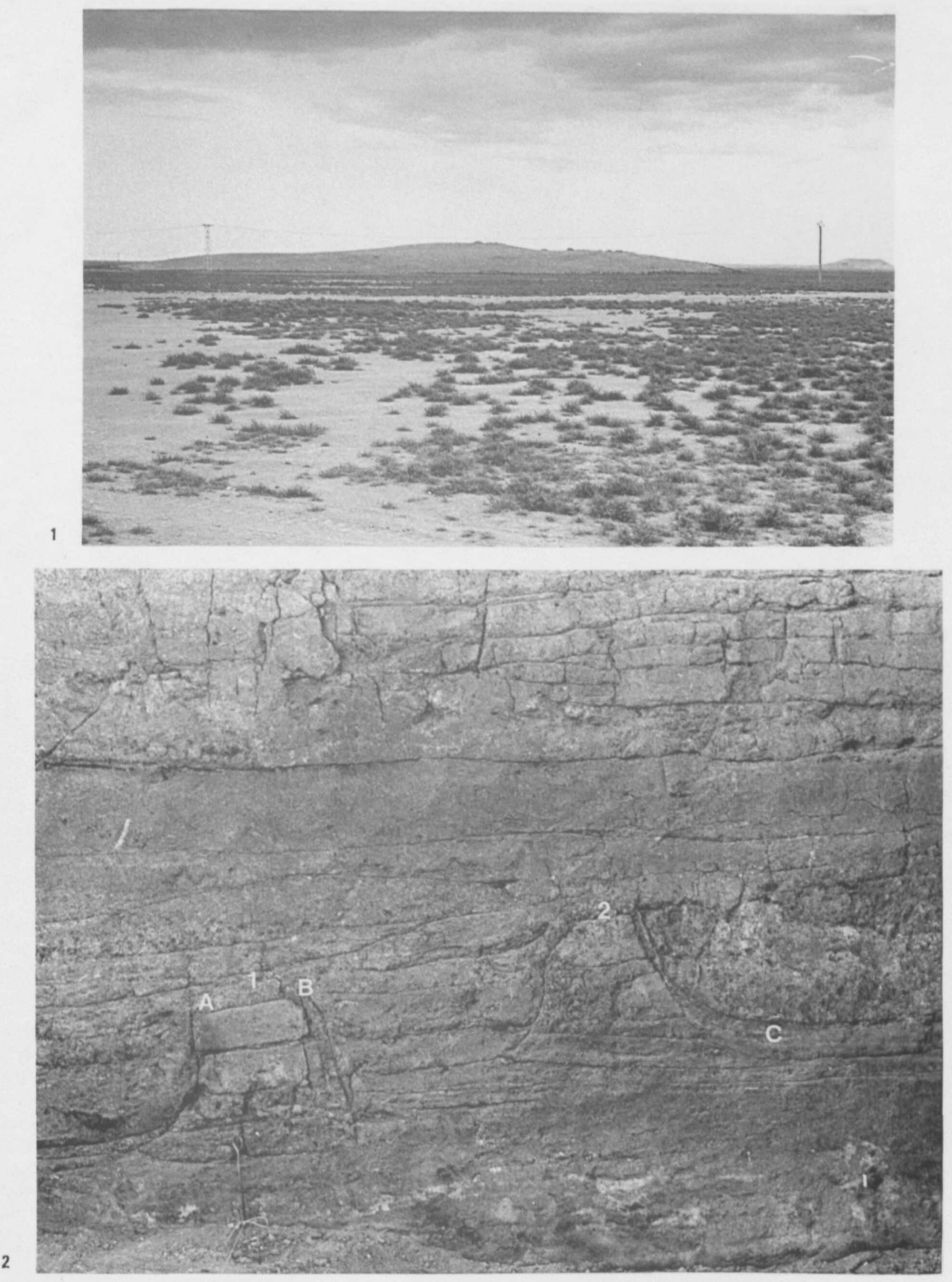

PI. I : 1. - View of Tell Sabi Abyad. On the background the large site of Tell Hammam et-Turkman.

PI. I : 2. - Part of the north section of square P14. The mud brick walls of two tholoi are visible (nos. 1 and 2). The dark left side of wall 1 shows the penetration of heat during the intentional burning of the tholos interior. On the right side (b), the exterior mud wall plaster is visible. Wall 2 clearly shows the burnt interior plaster carried up onto the lower wall (c). 


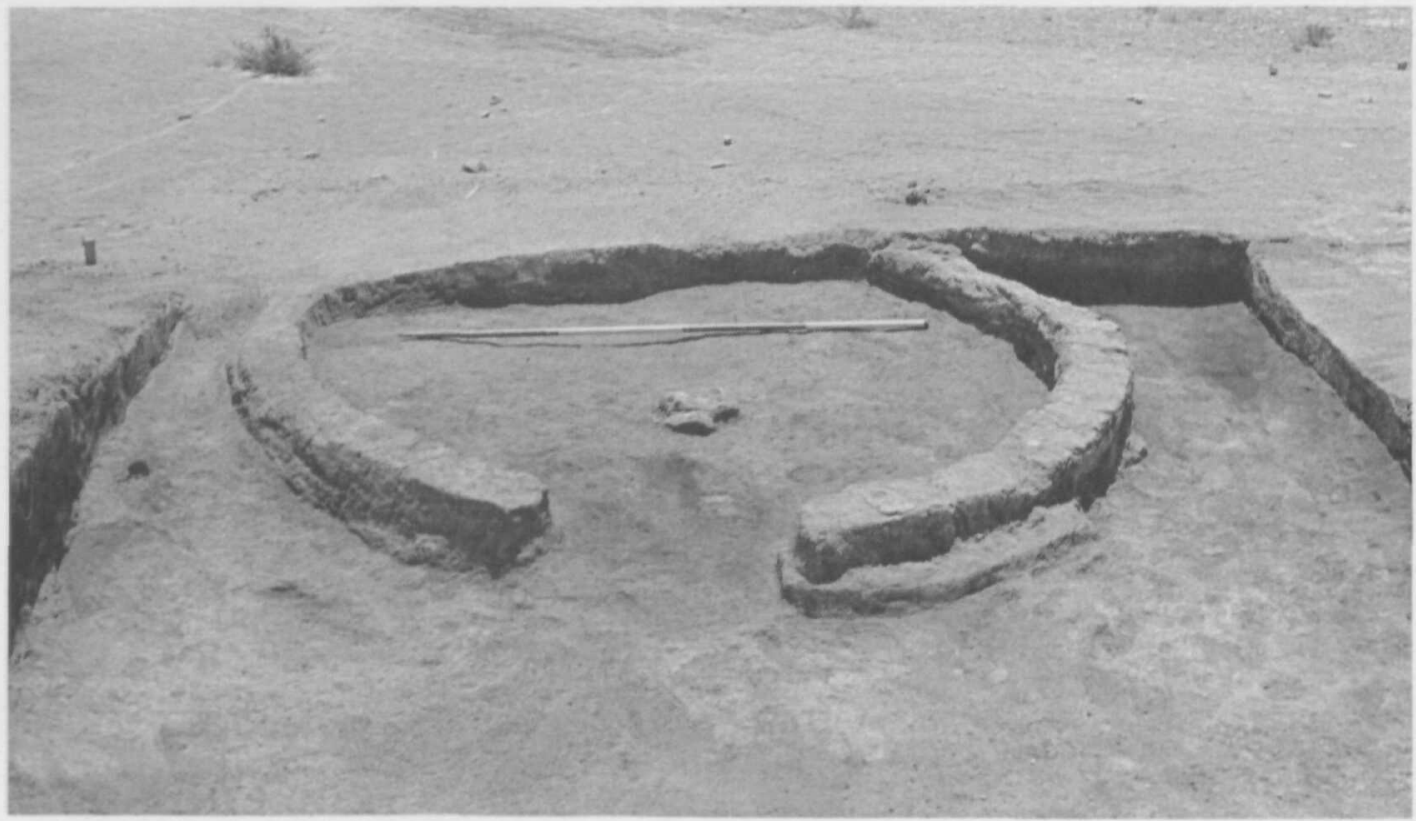

1

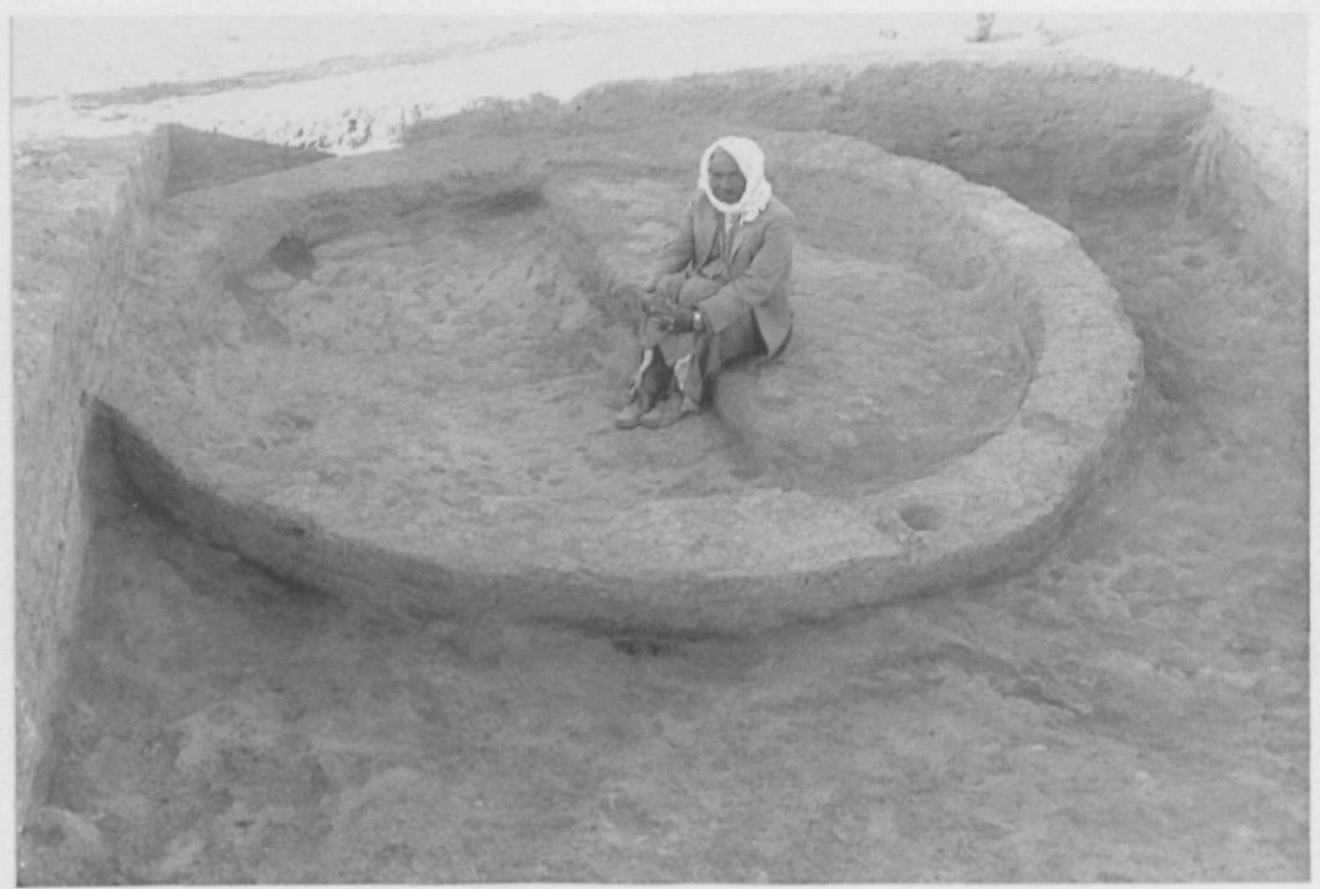

PI. II : 1. - Tholos in square P14, appearing immediately below the surface. The tholos was built upon the partly preserved remains of an earlier tholos. In its centre a stone platform for a wooden post is present.

PI. II : 2. - Tholos in square P14. In the doorway a hole serving as a door socket was present. This tholos was rebuilt twice. 

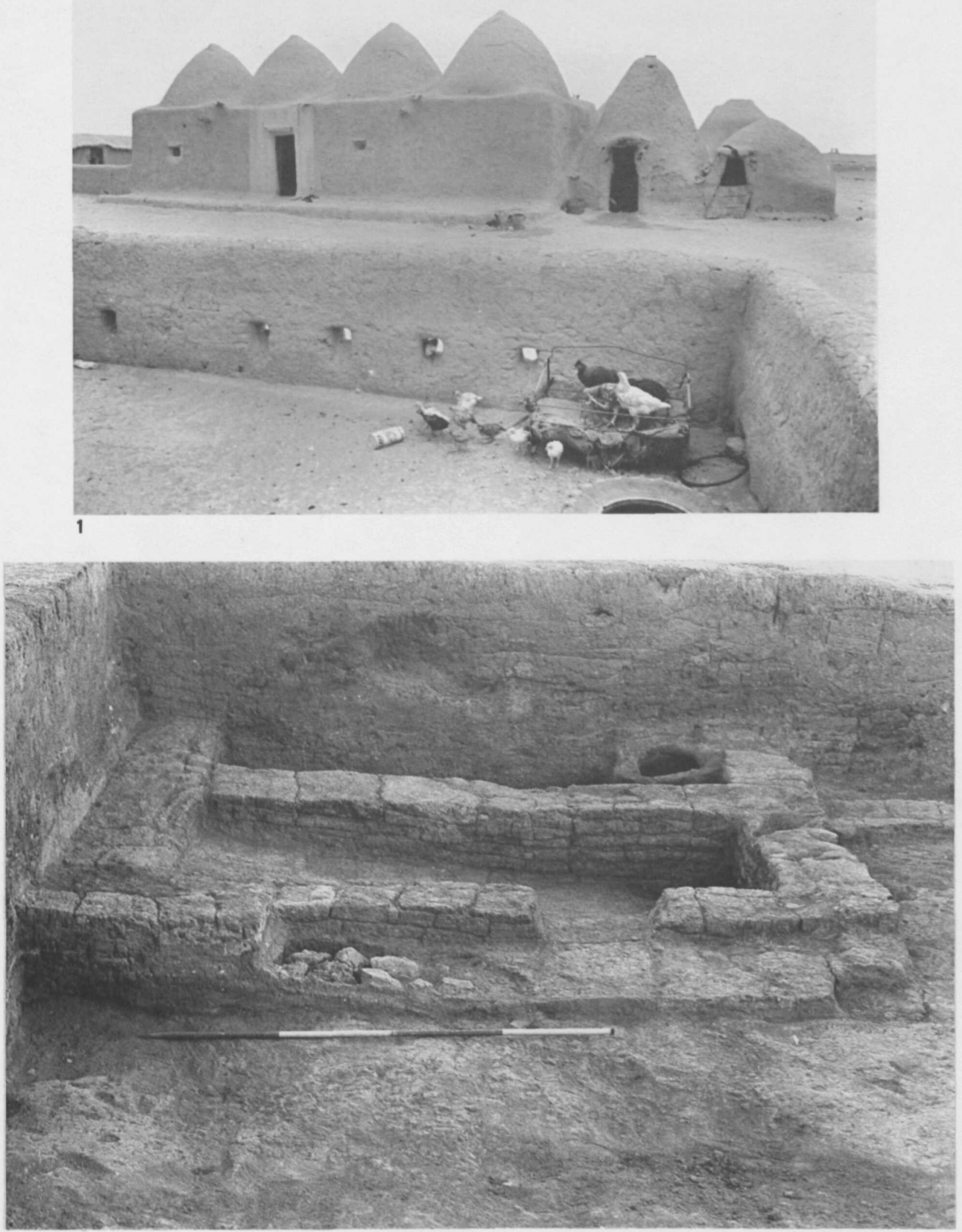

PI. III : 1. - Modern village architecture in the Balikh valley displays close similarities to Halaf buildings. This picture shows a rectangular house flanked by three small "tholoi". (photo : Ron Leenheer).

PI. III : 2. - Early Halaf main building in square P13. The building is constructed of thick mud brick walls on a stone foundation. A bench is present in front of the entrance. 

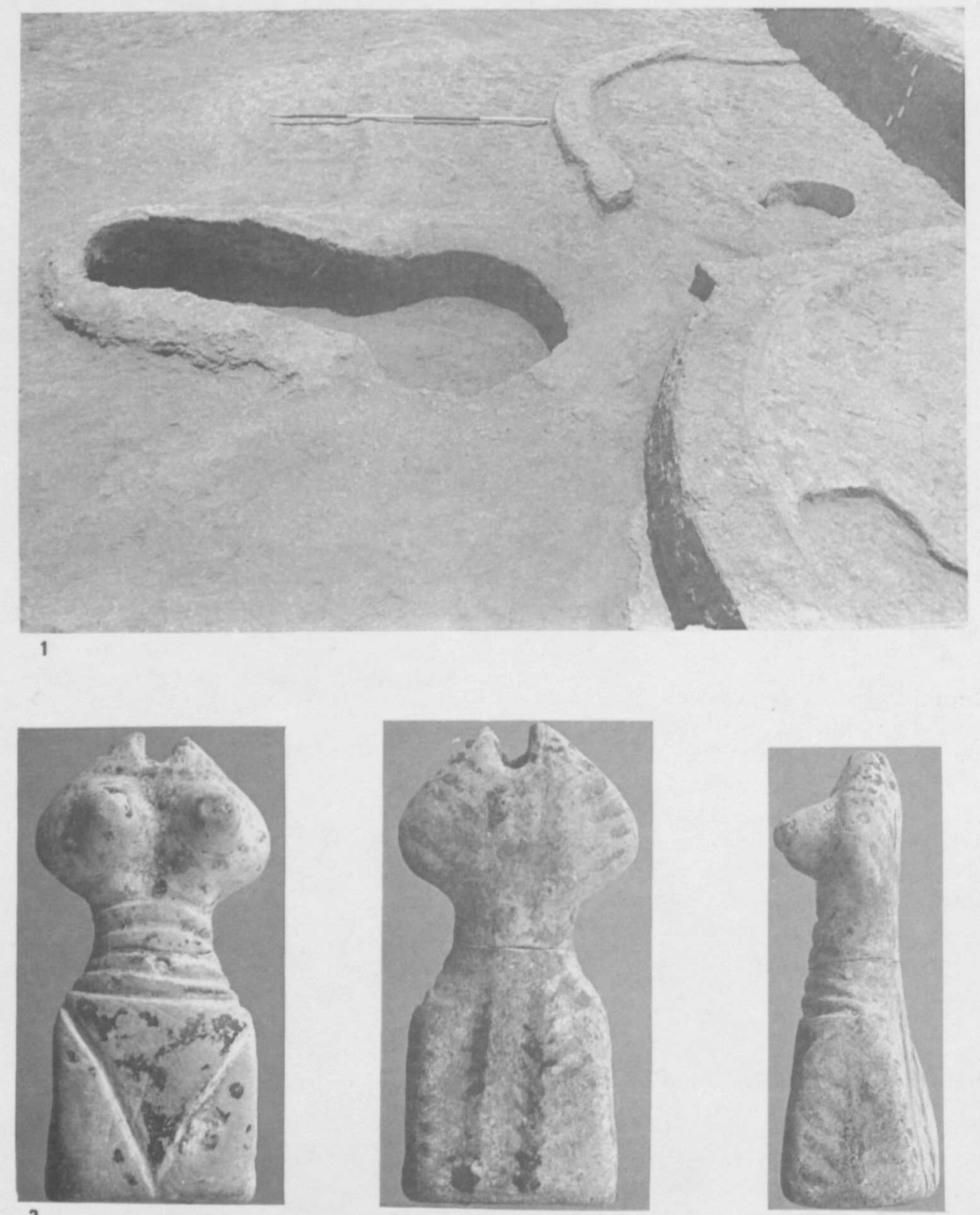

3

4

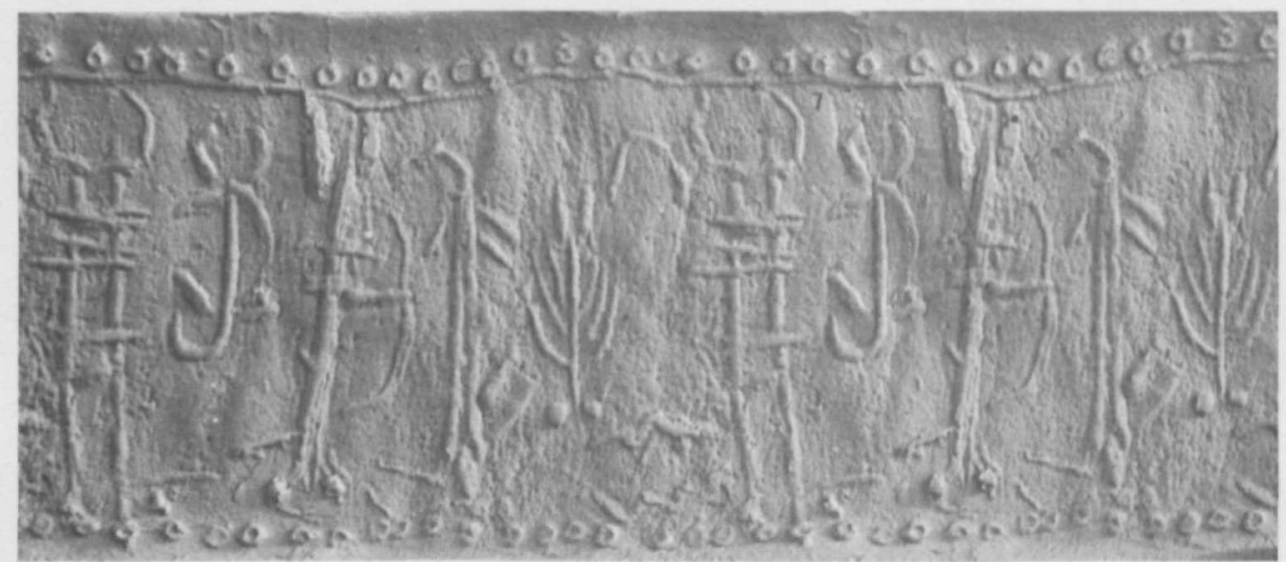

PI. IV : 1. - Keyhole-shaped kiln in square P13. On the right parts of two tholoi are visible.

PI. IV : 2. - Early Halaf female figurine from ashpit in trench T4. Baked clay. Actual height : $6,3 \mathrm{~cm}$.

PI. IV : 3. - Impression of clay cylinder seal or amulet (actual width of design : $4 \mathrm{~cm}$ ). 
Levant and Syria (27). It is not yet clear what reasons underlie this widespread desertion of sites. Perhaps an increasing aridity in large areas of the Near East took place in the late 7 th millennium B.C., forcing people to evacuate formerly inhabited areas (28).

The present evidence from the Balikh region suggests that although many sites were abandoned, the valley as a whole was not deserted. Occupation in this region apparently contracted to several large sites, one of which seems to be Tell Sabi Abyad. The first season of excavations at Sabi Abyad has yielded late Neolithic levels, provisionally related to Amuq B, on top of the northeast mound and underneath the early Halaf levels of the southeastern mound. On the former, an accumulation of at least five meters of pre-Halaf occupational remains still awaits excavation. Although 7th millennium levels have not yet been reached at Sabi Abyad, we expect that future fieldwork will reveal a continuous sequence of occupation at the site from the 7th millennium into the 6th millennium B.C.

The late Neolithic levels exposed at Tell Sabi Abyad immediately precede the early Halaf strata at the site. No true break in occupation seems to be present. This suggests that the introduction of Halaf in the Balikh valley should not be viewed as the implantation of a new culture in an otherwise empty and deserted area (29), but on the contrary as the dynamic replacement of local late Neolithic cultural traits by Halafian features. The rapid incorporation of local late Neolithic communities into Halaf society may be the result of the introduction of new and superior adaptive strategies towards daily subsistence needs (as reflected in the highly developed Halafian technology concerning pottery manufacture). The question whether the Halaf culture represents an intrusive element in the Balikh region or, on the contrary, should be viewed as an indigenous development cannot be answered definitely yet (30), but considering the available data it seems reasonable to suggest that the Balikh region forms part of the Halaf homelands. The absence of a stratigraphic break at Tell Sabi Abyad indicates a continuous development of occupation from the late Neolithic into the early Halaf period. This trend seems to be confirmed by the pottery recovered. In the late Neolithic levels at Sabi Abyad already a minor component of smoothed, grit-tempered and painted ceramics was found, which clearly differs from the commonly distributed coarse and plant-tempered pottery of these levels, and which thus may form a

(27) At Bouqras, for example, the main occupation areas are deserted after ca. 5900 B.C., although it was established recently that at least at part of the site occupation continued until about 5500 B.C. (M. LE MIÈRE, pers. communication).

(28) Cf. MELLAART, 1975: 67-69: MOORE, $1983: 99$

(29) As suggested e.g. by COPELAND, 1979:269

(30) When this article was written, only a limited amount of information recovered during excavations at Sabi Abyad had been processed. A detailed and quantitative analysis of the excavation's results is under way and will no doubt shed light on this highly important item. first step towards a technologically and aesthetically more developed kind of pottery. This trend finally culminates in the Halaf period. Throughout the Halaf sequence at Sabi Abyad, however, a group of coarse ware ceramics, hardly distinguishable from the earlier Neolithic coarse ware, is present, thus constituting an obvious link between the late Neolithic and early Halaf periods. A similar development is noticeable at sites in the northeastern part of the Syrian Jezirah, viz., Tell Halaf and Tell Aqab. At the former site, the lower levels seem to yield exclusively "Altmonochrome" pottery, followed at a later stage by a mixture of both Altmonochrome and painted Halaf pottery, until in the upper levels the Altmonochrome finally disappears (31). The transitional stage between Altmonochrome and early Halaf at Tell Halaf may date around 5600 B.C. (32). At Tell Aqab early Halaf levels were found immediately overlying virgin soil (33). Apparently no preHalaf levels are present, but the lower Halaf strata comprise a considerable amount (up to $37 \%$ ) of unpainted, straw-tempered and burnished ware, closely related to the Altmonochrome of Tell Halaf (34). The early Halaf pottery found at Tell Aqab closely compares to the ceramics from Tell Sabi Abyad.

After a prosperous period of some time, an end seems to come to Halaf village life at Sabi Abyad. The formerly inhabited areas of Tell Sabi Abyad are deserted after the early Halaf phase. However, the presence of a few probably middle Halaf sherds (unfortunately found in an unstratified context) seem to indicate that Tell Sabi Abyad as a whole was not abandoned, but that occupation shifted or contracted to another part of the site. Nevertheless, an important change in settlement organization seems to have taken place at Sabi Abyad. At this time, at the nearly site of Tell Damishliyya a small middle Halaf settlement existed, which may represent a seasonal camp site, repeatedly visited over a number of years (35). In the Balikh area several middle Halaf sites are present which show a close resemblance to Damishliyya. Perhaps at the end of the early Halaf period a shift in subsistence strategies took place, requiring a different mode of settlement structure. Our present evidence from the Balikh valley clearly indicates a twofold division in Halaf settlement organization, with rather large, long-term settlements on the one hand (e.g. Tell Sabi Abyad) and small, camp-like sites on the other hand (e.g. Tell Damishliyya). Probably an interaction existed between both types of settlements. At Damishliyya large quantities of well-made Halaf pottery appeared, but no kilns or the like were found. In view of this absence of indications for

(31) VON OPPENHEIM, $1943: 25$.

(32) VOGEL and WATERBOLK, $1964: 355$

(33) DAVIDSON and WATKINS, 1981: 4

(34) Ibid. : 7

(35) AKKERMANS, in press.

(36) DAVIDSON and McKERRELL, 1976. 
local pottery production, and in view of the specific knowledge necessary for the manufacture of pottery, it is certain that no Halaf ceramics were produced at the site of Damishliyya. Apparently its inhabitants depended on the presence of pottery production facilities at other sites, thus giving evidence of the existence of an intra-regional exchange network. In the upper Khabur region the existence of such an exchange network has already been solidly demonstrated for the latter part of the Halaf period (36).

\section{Peter M.M.G. AKKERMANS Institute of Pre- and Protohistory University of Amsterdam Singel 453 Amsterdam, the Netherlands}

\section{BIBLIOGRAPHY}

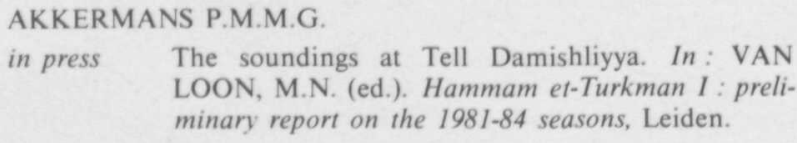

BRAIDWOOD R.J. and BRAIDWOOD L.S.

1960 Excavations in the Plain of Antioch, I, OIP, LXI, Chicago : University of Chicago Press.

\section{CAUVIN J.}

1972 Sondages à Tell Assouad (Djezireh, Syrie). Annales Archéologiques Arabes Syriennes 22: 85-88.

\section{COLLON D}

1982 The Alalakh cylinder seals. BAR Int. Ser. 132. Oxford.

\section{COPELAND L.}

1979 Observations on the prehistory of the Balikh valley, Syria, during the 7 th to 4 th millennium B.C. Paléorient $5: 251-275$.

\section{DAVIDSON T.E}

197

Regional variation within the Halaf ceramic tradition. University of Edinburgh.

DAVIDSON T.E. and McKERRELL H

1976 Pottery analysis and Halaf period trade in the Khabur headwaters region. Iraq $38: 45-56$

DAVIDSON T.E. and WATKINS T.

1981 Two seasons of excavation at Tell Aqab in the Jezirah, n.e. Syria. Iraq $43: 1-18$.

HOMES-FREDERICQ D. et al

1982 Les sceaux-cylindres de Syrie. Bruxelles: Musées royaux d'art et d'histoire.

LE MIÊRE M.

1979 La céramique préhistorique de Tell Assouad, Djezireh, Syrie. Cahiers de l'Euphrate 2: 4-76. Paris : CNRS.

MALLOWAN M.E.L.

1933 The prehistoric sondage of Nineveh, 1931-32. Annals of Archaeology and Anthropology 20 : 127-86.

MELLAART J.

1975 The Neolithic of the Near East. London : Thames and Hudson.

MERPERT N.Y. and MUNCHAEV R.M

1973 Early agricultural settlements in the Sinjar plain, northern Iraq. Iraq 35:93-113.

MOORE A.M.T.

1983 The first farmers in the Levant. In : CUYLER YOUNG Jr. T., SMITH P.E.L. and MORTEN SEN P. (eds.) The Hilly flanks and Beyond. $S A O C$ 36. Chicago : Oriental Institute.

MULDERS M.A.

1969 The arid soils of the Balikh basin (Syria). University of Utrecht.

TEISSIER B.

1984 Ancient Near Eastern seals from the Marcopoli collection. Berkeley etc. : University of California Press.

VOGEL J.C. and WATERBOLK H.T.

1964 Groningen radiocarbon dates V. Radiocarbon 6 : 349-369.

VON OPPENHEIM M.

1943 Tell Halaf I : die prähistorischen Funde. Berlin : Walter de Gruyter and Co. 